\section{人造 宝石}

\section{國富稔}

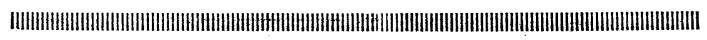

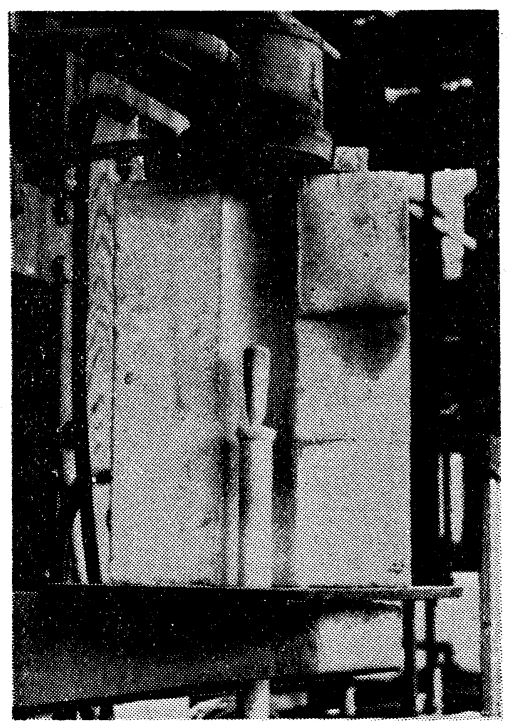

天然の結晶と全く同じ人工の結晶が最近多くの研究者 によってつくり出され, 「人工結晶」という新しい科学 的ならびに工業的部門が拓かれつつ ある。いまこれを製法に從って大別 すると次の 3 方式に区別できる。

1. 光学用結晶としての岩塩1の ように熔融塩を冷却して結晶させる 方法で, 岩塩の他に弗化りシウム $\left.(\mathrm{LiF})^{2}\right)$ 弗化カルシウム $\left(\mathrm{CaF}_{2}\right)^{3)}$ 工 業用原材料としての雲母（合成金雲 母 $\mathrm{KMg}_{3} \mathrm{AlSi}_{3} \mathrm{O}_{10} \mathrm{~F}_{2}$ ) ${ }^{4}$ ，石綿（拊肉 石采 $\left.\mathrm{F}_{2} \mathrm{Na}_{2} \mathrm{Mg}_{3} \mathrm{Fe}_{2}\left(\mathrm{Si}_{4} \mathrm{O}_{11}\right)_{2}{ }^{5}\right)$ など がある。

2. 圧電結晶としてのロッシェル

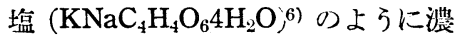
厚水溶液から析出結晶させる方法 で,これにはロッシェル塩の他に硫 酸 リシウム $\left(\mathrm{Li}_{2} \mathrm{SO}_{4} \mathrm{H}_{2} \mathrm{O}\right)$, 塩化銀 $(\mathrm{AgCl})$, 硝酸ナトリウム $\left(\mathrm{NaNO}_{3}\right)$ 第 一燐酸アンモニウム $\left(\left(\mathrm{NH}_{4}\right) \mathrm{H}_{2} \mathrm{PO}_{4}\right)$ 水晶 $\left(\mathrm{SiO}_{2}\right)^{7)}$, ェメラルド $\left(3 \mathrm{BeO} \cdot \mathrm{Al}_{2}\right.$ $\left.\mathrm{O}_{3} 6 \mathrm{SiO}_{2}\right)^{8)}$ などがある。

3. 上記の 2 方法と全く異るもの

カット：人造宝石製造裝虽
に Verneuil 法9) (火焰熔融法 flame fusion method)が ある。この方法は佛人 Verneuil (1891) が考案したも ので,ルビー (紅玉), サファイヤ (毒玉), スピネル (尖 晶石）などの貴石の製法に用いられて物り，最近では Rutile ${ }^{10)}$ (金紅石) や Mullite $\left(3 \mathrm{Al}_{2} \mathrm{O}_{3} \cdot 2 \mathrm{SiO}_{2}\right)^{11)} な と ゙$ の結晶の製造にも㗹用されている。これらの人工結晶の 中で宝石として珍重されるものる人造宝石といい，市場 では一括して synthetic の通称のもとにいろいうの宝石 が取り引きされているようである（第 1 表参照）。

しかしいずれる酸化アルミニウム $\left(\mathrm{Al}_{2} \mathrm{O}_{3}\right)$ を主原料 とし，これに少量の着色剤を加えた鋼玉系宝石と，酸化 アルミニウムと睃化マグネシウム $(\mathrm{MgO})$ を等モルに混 合し，これ行請色剂を加之た尖晶石系宝石とに大別され る。最近酸化テタン $\left(\mathrm{TiO}_{2}\right)$ 各原料とする Rutile が市 場にまらわ机にじめ Verneuil 法の新製品として話題と なっている。

わが䦨では昭和 9 年頃 日本㖉素肥料会䒬が朝鮮の興 南に日窒人造宝不株式会社興南工場を建設したのが最初 で, その後昭和 15 年に日本電興株式会社が小國に貴石 工場を設立した。終戰後に日窒の興南工場はなくなり， 現在で心小國の日本電興，旧第一海軍燃料廠內の信光社 が主としてルビー，サファイヤの製造をなしわが國の 時計工業，精密計器用の需姴に應じ，その生栍額は原石 として年額 200 万カラット $(1$ カラットほ $0.2 \mathrm{~g})$ に達 しているょうである。第 2 表にその主な用途を表示す る。

\section{人造宝石の製法 (Verneuil の法)}

ダイヤモンド, ルビーなどの貴石も他の 岩石と 同樣,

第 1 表 人造宝石の種類（主成分は $\mathrm{Al}_{2} \mathrm{O}_{3}$ )

\begin{tabular}{|c|c|c|c|c|c|c|}
\hline 鋼王系合成宝石 & \multicolumn{3}{|c|}{ 色合 } & 韶 & 色 & 戍 \\
\hline 1. ライト・ピンクサファイヤ & & & & $\mathrm{Cr}_{2} \mathrm{O}_{3}$ & $1 \sim 0$ & $5 \%$ \\
\hline 2. ピンク・ル ビ - & 桃 & & 色 & $\mathrm{Cr}_{2} \mathrm{O}_{3}$ & $L \sim 0.2$ & \\
\hline 3. ル ビ & 紅. & & 色 & $\mathrm{Cr}_{2} \mathrm{O}_{3}$ & $-3 \%$ & \\
\hline 4. ダン バ ラ イ & 橙 & & 色 & $\begin{cases}\mathrm{NiO} & 0 \\
\mathrm{Cr}_{2} \mathrm{O}_{3}\end{cases}$ & L & \\
\hline 5. バイオレット・サファイヤ & 荲 & & 色 & $\left\{\begin{array}{l}\mathrm{TiO}_{2} \\
\mathrm{Fe}_{3} \mathrm{O}_{4}\end{array}\right.$ & $\%$ & $\mathrm{O}_{3} 0.1 \%$ \\
\hline 6. ブルー・サファイヤ & 青 & & 色 & $\left\{\begin{array}{l}\mathrm{TiO}_{2} \mathrm{O} \\
\mathrm{Fe}_{2} \mathrm{O}_{3}\end{array}\right.$ & & \\
\hline 7. アレキサンドライト & $\begin{array}{l}\text { 青紫 } \\
\text { 赤步 }\end{array}$ & $\begin{array}{c}\text { 日 } \\
\text { 電 }\end{array}$ & & $\mathrm{V}_{2} \mathrm{O}_{3} 3$ & $4 \%$ & \\
\hline 8. ト パ - ズ & 黃 & 金 & 色 & $\left\{\begin{array}{l}\mathrm{NiO} 0 \\
\mathrm{Cr}_{2} \mathrm{O}_{3}\end{array}\right.$ & 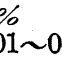 & \\
\hline 9. イエロー・サファイヤ & 黄 & & 色 & $\mathrm{NiO} 0$. & -1.0 & \\
\hline 10. ホワイト・サファイヤ & 無 & & 色 & な & & \\
\hline 尖晶石系宝 石 & & & & & & \\
\hline 1. ライト・アクアマリン & 青 & 空 & 色 & $\mathrm{CoO} 0$. & $\sim 0.0$ & \\
\hline 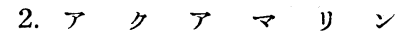 & 海 & 水 & 色 & $\mathrm{CoO} 0$. & -1.0 & \\
\hline 3. $\times \quad \bar{~}$ & 淡 & 綠 & 色 & $\left\{\begin{array}{l}\mathrm{CoO} 0 \\
\mathrm{MnO}\end{array}\right.$ & 0 & \\
\hline 4. ス & 青 & 紫 & 色 & $\mathrm{CoO} 0$. & -1.5 & \\
\hline
\end{tabular}


第 2 表 人造宝石（主としてルビー, サファイヤ)の用途

\begin{tabular}{l|l}
\hline 1. 時計工業用 (軸 受) & 7. 錄音器用サファイヤカッター
\end{tabular}

2 - 電氣指示計器用軸受 8. 電堺用サファイヤ, 針, バイト

3. 鉄道信号用継電器穴石 9. 高級 度 量 衡器 用

4. 船舶用羅計儀軸受 10. レイヨン用サファイヤガイド

5. 遠心分離機用ノッズル 11. 研䐴成用

6. 積算電力計器用軸受 12 . 裝身具用 (指環, 首飾り等)

かりて地球が熔融狀態から次第に冷却して固化していく 過程に特いて同一成分のものが集結し，これらか溡殊の 狀態 (高溫高圧) 下で徐冷される場合次第に大きな結晶 となったのであろう。かく考えると貴石類のみならず容 易に結晶を形成するものであれば，いずれでもこれを熔 融し, 適当な環境のもとに徐冷していけば大きな單結晶 が得られるという考えが礦物合成の基となっていると思 う。この中で宝石と称せられるものはその使用目的から して，美しいこと，光学的に質が一樣で透明であるこ と, 加工が可能な狀態であることなどの要求から結晶形 完全な，乙か子なるべく大きな單結晶をつくることが必 要である。その上宝石の主成分である $\mathrm{Al}_{2} \mathrm{O}_{3}, \mathrm{SiO}_{2}$, $\mathrm{MgO}, \mathrm{TiO}_{2}$ などはいずれも熔融点高く $\left(2000^{\circ} \mathrm{C}\right.$ 內外 $)$ 純粹な状態で熔融が困䧼でその容器さえも邀当なるのが ない。また微量の鉄粉が入っても多くは茶褐色に着色 乙, 他の微量の無色の不純物でもそのイオン怆徍（原子 牛烽) が主原料のそれとほなはだしく暴れば結晶の生成 を妨げ，また氣泡が入っても結晶が生長しない。たとえ できても量ったり，脆い結晶となる。そこで容器を用い ないで, 結晶生成中に他から不純物や氣泡の原因である 氣体の混入を避け，乙かる大きな單結晶を得ようと考え たのが Verneuil の法で, 第 1 罒に示したものは当研 究公で Verneuil の方法を Rutile に礁用すべくバーナ 一に改良を加えたるのである。この方法は酸水素焰中に 原料粉末を落しながら熔融し結晶を生長させるもので,

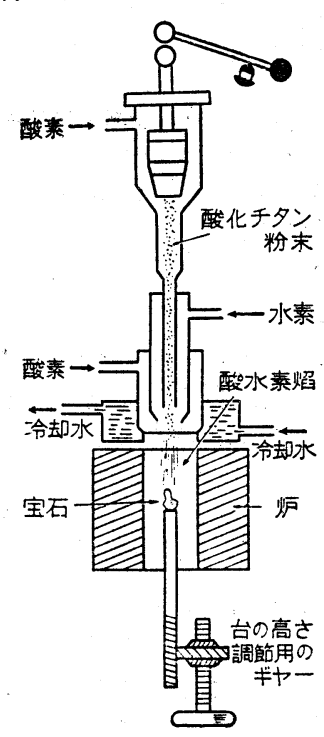

第 1 図 操作の大要を述べると, 上部 のホッパー中の原料粉末容器 の底は金網 $(100$ メッシュ程 度) でつくられ, 最上部のバ イブレーターで容器の頭部を 打つと小量づつ原料粉末が落 ちるようになっている。落下 粉はバーナーの內管, すなわ ち酸素管を通って受器の上に 溜る。水素はバーナーの外管 を通り，バーナーの先端て酸 素々合して燃え, その燃燒熱 で合成炬の溫度は $2000^{\circ} \mathrm{C} に$ 達する。原料粉末はこの酸水 素焰中を落下し, 牛熔融狀態 で熘の先端附近にある受器 (アルミナ製耐火棒) の上に 蓄積され燒結した錐狀体をつ くる。酸素及び水素の流量を
加減して噵当な溫度で錐狀体の頂部を熔融させると， 漸時にして透明な結晶核となりこれが徐々に生長し て大きな單結晶塊となるのである。この結晶核の觡不 週は結晶の生命を支配するもので，この作業のもっと も重要な点の一つである。

結晶塊がだんだん太く長くなると耐火棒の受器を少 しづつ下げて常に結晶の上部が䡒の最高溫度中にある ように調節する。結晶塊の頂部 $1 \mathrm{~mm}$ 程度の層は常に 熔融狀態に保つょうに溫度を加減し，落下粉はこの層 內で完全に熔融し，熔融層の下部の結晶面に析出してい くのである。Rutile の場合バーナーを三重にしたのは

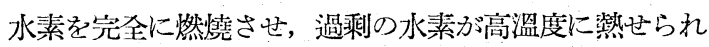

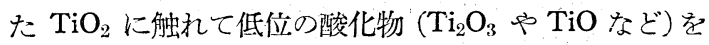
生成することを防ぎ，かつ㷪の橫の盜度差を少くして結 晶塊 (Boule) 太くするためである。实際の作業に当っ ては原料粉末の落下速度, 火焰溫度の調節（水素, 酸素 ガスの流量調節）が boule の生命を左右するので,かな り熟練を要する。1 台り合成炉で順調に操作が行われた とき，數時間で 200 カラット程度の原石が得られる。一 旦操作法が倠立すればこのバーナーを数多く連立して作 業ができるが相当性能の優秀なガス圧調節器を必要とす る。しかし Rutile の場合はルビーに比べて融点が低く (1840ㄷ 位) かえって操作がもずかしい上うで 1 人で 何台作業を担当することは困難である。

\section{人造宝石の原料}

人造宝石に用いられる原料は前述の上万に使用目的及 び結晶生成の過程からして極めて綍度の高いことを要求 される。普通その程度はスペクトル分析によって吟味す

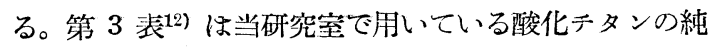
度の程度を示す。

また人造宝石の原料として久くことのでき㛆件とし ては純度のほか，一定の物理的性質が必要である。それ はバイブレーターによって原料容器の金網から常に一定 量が落下されなければなら始から粒子が一樣で量的に変

第 3 表 宝石合成用酸化チタンの純度 ${ }^{12}$

\begin{tabular}{c|c|c}
\hline \hline 不純物の種頪 & 最優秀原料 $(\%)$ & 普通の原料 $(\%)$ \\
\hline $\mathrm{SiO}_{2}$ & $<0.02$ & $<0.04$ \\
$\mathrm{Fe}_{2} \mathrm{O}_{3}$ & $<0.001$ & $<0.001$ \\
$\mathrm{Al}_{2} \mathrm{O}_{3}$ & $<0.001$ & $<0.001$ \\
$\mathrm{Sb}_{2} \mathrm{O}_{3}$ & $<0.002$ & $<0.002$ \\
$\mathrm{SnO}_{2}$ & $<0.001$ & $<0.001$ \\
$\mathrm{Mg}$ & $<0.0005$ & $<0.001$ \\
$\mathrm{Cu}$ & $<0.001$ & $<0.001$ \\
$\mathrm{~Pb}$ & $<0.002$ & $<0.002$ \\
$\mathrm{Mn}$ & $<0.00005$ & $<0.0001$ \\
$\mathrm{~W}$ & $<0.005$ & $<0.01$ \\
$\mathrm{~V}$ & $<0.0005$ & $<0.002$ \\
$\mathrm{Ca}$ & $<0.01$ & 不 \\
$\mathrm{Cr}$ & $<0.0001$ & "明 \\
$\mathrm{Ba}$ & $<0.001$ & $\prime \prime$ \\
\hline
\end{tabular}


化なく金網を通るようになっていなければならぬ。あま りに微粉に過ぎると粉末同志が附着して，大きな固塊に なったり，また落下の途中酸素管壁やバーナーの先端に 附着したりして作業の中止を余儀なくされることさえあ る。このような現象はある程度粉末の粒子の大きさ, 刓 狀，吸濕の程度などに原因する。從って原料の調製には これらの惡條件をなくするために原料の製法, すなわち 燒成する直前の狀態と燒成溫度, 時間などに細心の注意 を要する。また原料粉が結晶塊上に落下するやすぐに 完全熔融することが必要であるからごく微細結晶でなけ ればならない。この三つの相反する條件を満足させるた め多孔性である程度嵩比重の小さい粉末が要求される。 普通ルビー, サファイヤの原料である宝石用アルミナは 純度の高いアンモニヤ明攀を前述の條件に合致するよ 万盜度，時間に注意して燒成する。また Rutile の場合 は四塩化チタン, 硫酸アンモニウム, 硫酸, 水(いずれ る精製したもの) を適量に化合させて得られる, アンモ ニウム, 一テタ $=$ ール, 一サルフェート $\left(\left(\mathrm{NH}_{4}\right)_{2} \mathrm{TiO}\right.$ $\left.\left(\mathrm{SO}_{4}\right)_{2} \cdot 2 \mathrm{H}_{2} \mathrm{O}\right)^{13)}$ を燒いて酸化チタンにしたものを用い る。よい boule（第 2 図参照）か得られるか否かは原料

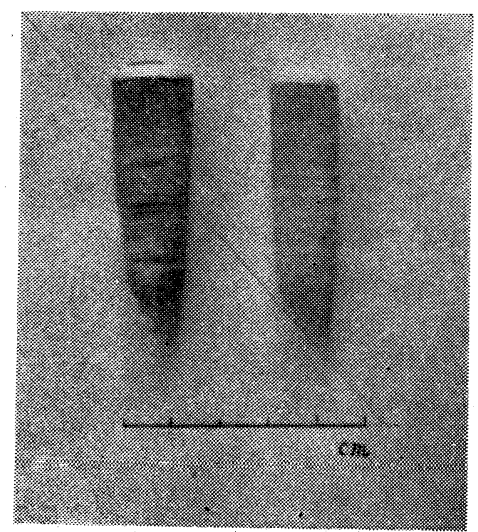

第 2 図
粉末の純, 不純と 物理的性質の通,

不阎にあってバー ナーの制御ととひ に人造宝石の作業 の重要な点であ る。つぎの第 4 表 に当研究室で用い ている酸化テタン の物理的性質の一 部を拔粹して示 す。ルビー,サフ アイヤなどの現在 ぞこの市場でも取
宝石として用いられるものもあるという。，その成分は酸 化テタン $\left(\mathrm{TiO}_{2}\right)$ で正方晶系 (第 3 図参照) に結晶し, 透電率の高いことで有名である。硬度 6〜6.5 (合成の\& の $7 \sim 7.5)$ 比重 4.2 , 融点約 $1840^{\circ} \mathrm{C}$, 屈折率 $2.6 \sim 3.1^{14)}$ (ダイヤ 2.42) (第 5 表参照) で複屈析をなし, 分散能 はダイヤの約 5.7 倍である。從って無色の單結晶を適当 にカットしよく研暨すれば非常によく輝き，特に夜の電 燈下ではすばらしい。

1947 年頃か らアメリカの The Linde Air Products ¿ The National Lead Co. の 2 社で人 エルチルの製造 がはじめられ, 前者は Titania Gem, 後者は Night Stone の名で賣り出さ れた。当研究室 でも同じ頃から 研究をなし, 設 備の完成に二,

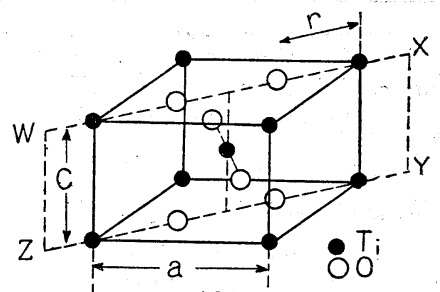

(a)

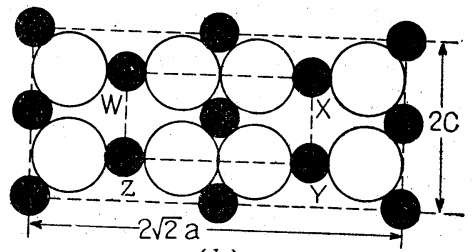

(b)

第 3 図

第 5 表 Refractive index

\begin{tabular}{c|c|c}
\hline \hline \multirow{2}{*}{ Wavelength $(\AA)$} & \multicolumn{2}{|c}{ Refractive index } \\
\cline { 2 - 3 } & Ordinary R. I. & Upper R. I. \\
\hline $6708(\mathrm{Li})$ & 2.5361 & 2.8141 \\
$5893(\mathrm{Na})$ & 2.6104 & 2.8729 \\
$5350(\mathrm{Tl})$ & 2.6601 & 2.9329 \\
$4358(\mathrm{Hg})$ & 2.8482 & 3.1771 \\
\hline
\end{tabular}

第 4 表 宝石合成原料の物理的性質

\begin{tabular}{|c|c|c|c|c|c|c|c|c|}
\hline 番号 & 種 類 & $\begin{array}{l}\text { 粗瑷 } \\
\text { 比重 }\end{array}$ & $\begin{array}{l}\text { 密嵩 } \\
\text { 比重 }\end{array}$ & $\begin{array}{l}\text { 見掛 } \\
\text { 比重 }\end{array}$ & 畺比重 & 氣孔率 & 吸油量 & 備 \\
\hline No. 1 & & 0.17 & 0.29 & 3.261 & 3.486 & 6,5 & 198 & \multirow{5}{*}{$\begin{array}{l}\text { ルビー, サファイヤ原料 } \\
\text { ルチル原料 } \\
\text { ルチルの優秀原料 }\end{array}$} \\
\hline No. 2 & $\begin{array}{l}\text { 酸 化 } \\
\text { 于タz之 }\end{array}$ & 0.44 & 0.92 & 3.545 & 4.001 & 11.4 & 64 & \\
\hline No. 3 & " & 0.31 & 0.58 & 3.485 & 4.196 & 17.0 & 120 & \\
\hline No. 4 & " & 0.41 & 0.84 & 3.638 & 4.070 & 10.6 & 88 & \\
\hline No. 5 & " & 0.57 & 0.94 & 3.950 & 4.126 & 4.3 & 88 & \\
\hline
\end{tabular}

三年のおくれをみたが，最近は 月産 3000 カラッ程度生産乙 て括り，一，二の民間工場にも 生産を許したので近く市場にあ らわれることと思 5。このチタ ンダイヤは淡い黃色の色調をむ っているが, 青色, 青黑色, 赤 褐色のるのも人造できる。この 色調はルビー, サフノイヤのよ 5に着色剂を加之て得たるのと

り抔われているものは，天然，人造を問わず，かなり人 に知られているので省略し, 最近人造宝石のダークホ ースとして話題となっている Rutileの紹介をしてタた い。

Rutile (金紅石) 当研究公でチタンダイヤモンドと名 付けた。

この原石は原名を Rutile といい,ブラジル, オース トラリヤ，などに天然に童し，通常不純物のため褐色を 景しており, 稀に深青色, 深紅色, 無色のものもまって
異り, 酸化ホタン独得の化学的性貿によるるのである。 すなおち $\mathrm{TiO}_{2}$ は高溫では極めて容易飞還元され易く， 合成炸中で結晶が生長する際水素ガスに触れ，一部が低 級酸化物 $\left(\mathrm{TiO}, \mathrm{Ti}_{2} \mathrm{O}_{3}\right)$ となるので, 之の低酸化物の色 を蚛らするのと考えられる。從って合成炉から取り出 した boule は普通不透明な青黑色で断面结金属光沢を 有している。この色調は $\mathrm{Ti}: \mathrm{O}$ の比によって変るもの で, 不透明な boüle を酸素または空氣流中で加熱する と酸素分吸收され，㱠えど完全に低酸化物に $\mathrm{TiO}_{2}$ に酸 
第 6 表 Hardness of $\mathrm{TiO}_{2}$ Crystals by Knoop Microindentation Method

\begin{tabular}{|c|c|c|c|c|c|c|c|c|}
\hline \multirow{3}{*}{ Sample } & \multicolumn{4}{|c|}{ Orientation } & \multirow{3}{*}{$\begin{array}{c}\text { Pyramid } \\
\text { Face Cut, } \\
45^{\circ} \text { to } \\
\text { "c" } \\
\text { Axis }\end{array}$} & \multicolumn{3}{|c|}{ Standard } \\
\hline & \multicolumn{2}{|c|}{$\begin{array}{l}\text { Basal Plane } \\
\text { Perpendicular } \\
\text { "c" Axis }\end{array}$} & \multicolumn{2}{|c|}{$\begin{array}{c}\text { Prism Face } \\
\text { Parallel "c" } \\
\text { Axis }\end{array}$} & & \multirow{2}{*}{ Mineral } & \multirow{2}{*}{$\begin{array}{l}\text { Mohs } \\
\text { Hardness }\end{array}$} & \multirow{2}{*}{$\begin{array}{l}\text { Indenta- } \\
\text { tion } \\
\text { No. }\end{array}$} \\
\hline & $\begin{array}{l}\text { Parallel } \\
\text { One } \\
\text { Prism }\end{array}$ & $\begin{array}{l}\text { Parallel } \\
\text { Other } \\
\text { Prism }\end{array}$ & $\begin{array}{l}\text { In } \\
\text { Direction } \\
\text { of " } c \text { " } \\
\text { Axis }\end{array}$ & $\begin{array}{l}\text { Per } \\
\text { Pendicu- } \\
\text { lar to "c" } \\
\text { Axis }\end{array}$ & & & & \\
\hline $\begin{array}{l}\text { Perfectly orientated } \\
\text { colorless cube .......... }\end{array}$ & \multirow[t]{2}{*}{898} & \multirow[t]{2}{*}{898} & \multirow[t]{2}{*}{$805 a$} & \multirow[t]{2}{*}{840} & \multirow{5}{*}{$\begin{array}{l}940 \\
890\end{array}$} & \multirow{5}{*}{$\begin{array}{l}\text { corundum } \\
\text { topaz } \\
\text { quartz } \\
\text { orthoclass }\end{array}$} & \multirow{2}{*}{$\begin{array}{l}9 \\
8\end{array}$} & \multirow{2}{*}{$\begin{array}{l} \pm 1,800 \\
\pm 1,200\end{array}$} \\
\hline $\begin{array}{l}\text { Yellowish over-oxidi- } \\
\text { zed crystal .............. }\end{array}$ & & & & & & & & \\
\hline $\begin{array}{l}\text { Light blue partially } \\
\text { reduced cube .......... }\end{array}$ & 750 & 850 & $831 \mathrm{a}$ & 835 & & & 7 & $\begin{array}{l}790 \\
710\end{array}$ \\
\hline Dark blue cube ...... & 766 & 840 & $859 a$ & 885 & & & 6 & $600-690$ \\
\hline Black ...................... & 940 & 950 & $1,000 \mathrm{a}$ & 767 & & & & \\
\hline
\end{tabular}

a: Indicates erroneous readings caused by excessive brittleness.

第 7 表 Change of Properties Upon Reduction

\begin{tabular}{|c|c|c|c|c|c|c|c|}
\hline \multirow{2}{*}{$\begin{array}{l}\text { No. of } \\
\text { Reduction } \\
\text { Exposure }\end{array}$} & \multirow{2}{*}{$\begin{array}{l}\text { Crystallo- } \\
\text { graphic } \\
\text { Direction }\end{array}$} & \multicolumn{2}{|c|}{ Oriented Cube } & \multicolumn{2}{|c|}{$\begin{array}{l}\text { Rectangular with Long } \\
\text { Direction Parallel to } \\
\text { "c" Axis }\end{array}$} & \multicolumn{2}{|c|}{$\begin{array}{l}\text { Rectangular with Long } \\
\text { Direction Parallel to } \\
\text { "c" Axis }\end{array}$} \\
\hline & & $\begin{array}{l}\text { Dielectric } \\
\text { Constant }\end{array}$ & $\begin{array}{l}\text { Resistivity } \\
(\mathrm{ohm} \mathrm{cm})\end{array}$ & $\begin{array}{l}\text { Dielectric } \\
\text { Constant }\end{array}$ & $\begin{array}{l}\text { Resistivity } \\
\text { (ohm } \mathrm{cm})\end{array}$ & $\begin{array}{l}\text { Dielectric } \\
\text { Constant }\end{array}$ & $\begin{array}{l}\text { Resistivity } \\
\text { (ohm cm) }\end{array}$ \\
\hline \multirow[t]{3}{*}{0.} & a & 655 & $3.14 \times 10^{9}$ & 149 & $15.0 \times 10^{12}$ & 187 & $3.79 \times 10^{12}$ \\
\hline & a & 275 & $4.5 \times 10^{10}$ & & & & \\
\hline & c & 83.5 & $1.55 \times 10^{13}$ & & & & ‥ \\
\hline \multirow[t]{3}{*}{1.} & $\mathrm{a}$ & $4.9 \times 10^{4}$ & $1.7 \times 10^{5}$ & $4.68 \times 10^{4}$ & $1.13 \times 10^{5}$ & $2.34 \times 10^{4}$ & $4.73 \times 10^{5}$ \\
\hline & $\mathrm{a}$ & $3.88 \times 10^{4}$ & $4.82 \times 10^{5}$ & & & & \\
\hline & c & $3.16 \times 10^{4}$ & $6.33 \times 10^{3}$ & & & & \\
\hline \multirow[t]{3}{*}{2.} & $\mathrm{a}$ & $5.7 \times 10^{4}$ & $3.82 \times 10^{4}$ & $5.35 \times 10^{4}$ & $2.35 \times 10^{6}$ & $3.01 \times 10^{4}$ & $7.12 \times 10^{5}$ \\
\hline & $\mathrm{a}$ & & $1.92 \times 10^{4}$ & & & & \\
\hline & & & $3.0 \times 10^{4}$ & & & & \\
\hline \multirow[t]{3}{*}{3.} & $\mathrm{a}$ & $4.58 \times 10^{4}$ & $4.2 \times 10^{4}$ & $4.15 \times 10^{4}$ & $3.39 \times 10^{5}$ & $2.22 \times 10^{4}$ & $9.5 \times 10^{5}$ \\
\hline & $\mathrm{a}$ & $4.58 \times 10^{4}$ & & & & & \\
\hline & $\mathrm{c}$ & & $1.55 \times 10^{4}$ & & & & \\
\hline \multirow[t]{3}{*}{4.} & $\mathrm{a}$ & $4.42 \times 10^{4}$ & $1.275 \times 10^{5}$ & $2.95 \times 10^{4}$ & $2.82 \times 10^{6}$ & $1.59 \times 10^{4}$ & $2.37 \times 10^{7}$ \\
\hline & a & $4.24 \times 10^{4}$ & $2.24 \times 10^{5}$ & & & & \\
\hline & c & $3.64 \times 10^{4}$ & $1.55 \times 10^{5}$ & & & & \\
\hline \multirow[t]{3}{*}{5.} & $\mathrm{a}$ & $4.31 \times 10^{4}$ & $2.55 \times 10^{4}$ & $3.17 \times 10^{4}$ & $2.62 \times 10^{6}$ & $1.62 \times 10^{4}$ & $1.66 \times 10^{6}$ \\
\hline & $\mathrm{a}$ & $4.37 \times 10^{4}$ & $4.82 \times 10^{4}$ & & & & \\
\hline & c & $4.8 \times 10^{4}$ & $2.64 \times 10^{4}$ & & & $1-00-101$ & \\
\hline \multirow[t]{3}{*}{6.} & $\mathrm{a}$ & $4.2 \times 10^{4}$ & $2.12 \times 10^{4}$ & $3.22 \times 10^{4}$ & $2.82 \times 10^{5}$ & $1.79 \times 10^{4}$ & $9.47 \times 10^{5}$ \\
\hline & $\mathrm{a}$ & $3.53 \times 10^{4}$ & $7.0 € \times 10^{4}$ & & & & $\therefore$ \\
\hline & c & $4.7 \times 10^{4}$ & $2.18 \times 10^{4}$ & & 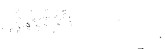 & & \\
\hline \multirow[t]{3}{*}{7.} & $\mathrm{a}$ & $4.25 \times 10^{4}$ & & $3.27 \times 10^{4}$ & $9.42 \times 10^{5}$ & $1.81 \times 10^{4}$ & \\
\hline & $\mathrm{a}$ & $3.88 \times 10^{4}$ & $8.02 \times 10^{4}$ & & & & $9.47 \times 10^{5}$ \\
\hline & $\mathrm{c}$ & $5.67 \times 10^{4}$ & $4.97 \times 10^{4}$ & & & 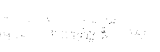 & \\
\hline 8. & \multicolumn{7}{|c|}{$\begin{array}{l}\text { All samples indicate strong decay of dielectric constant during measurement. } \\
\text { Cannot measure dielectric constant-resistivity too low. }\end{array}$} \\
\hline
\end{tabular}


化されて無色となる。この際酸化が十分行われないと き, また溫度, 時間か邂当でない子過酸化物 $\left(\mathrm{Ti}_{2} \mathrm{O}_{5}\right)$ が できいずれの場合も無色とならない。すなわ方，もし 酸化が不足であったり過大に過ぎると

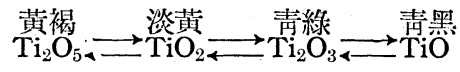

のいずれか偏して一層着色する。酸化チタンの他の特 質として，この結晶は $4300 \AA$ 附近の光線学殆んど完全 に吸收与る性能を有しているから $\mathrm{TiO}_{2}$ それ自体は無色 であるべきはずであるが余色が强くめらわれて黃色を呈 する。從って完全に無色の宝石を得ることは困難と想像 される。單結晶の既知の特質である誘電率は X 及び $\mathrm{Y}$ 方向で約 $90, Z$ 方向で約 180 を有しているが低酸化物 か゚含有されれば急增する。前ぺージの第 6 表15)，第 7 表にその人工結晶について屈折率, 硬度, 透電率の变化 のありさまを示した。

Rutile は人造宝石の中でも宝石としては優秀なもの でダイヤの代用品として，よろこばれているが，いまだ 工業的用途がない。しかし前述のような特性からして研 究の進むにつれて物理関係, 電氣関係になんらかの形で 用途が拓けると思万。

な和以上の他当研究室でほ一連の研究として, 水晶, エメラルド，石綿，結晶学見地から考えた新肥料なぞの 合成の研究を続行して未り，石綿，水晶はその合成に成 功基礎の域觉脱して中間工業実臉に入っているが，これ らについては後日の穖会に割愛する。

(山梨大学工学部應用化学敎室)

\section{文献}

1）榊米一郎：礁用物理 20 (1951) 89.

2) R. Kiyama: Rev. Phys. Chem. Japan. 20 (1951) 69.

3) D. C. Stockbarger: J. Opt. Soc. Am. 39 (1949) 73.

4）野田稻吉：工栄物理化学 第 1 輯 p. 103 119. 第 2 輯 p. 179 204.

5) 斎藤肇：工業化学 56 (1953) 756.

6）石川朝邦：音響 1 (1947) 92.

7) I. I. Friedman: Amer. Mineral 34 (1949) 583. C. S. Brown: Nature 167 (1951) 940.

8) A. F. Rogers. : Amer. Mineral 27 (1942) 762. A. E. Alexander : J. Chem. Educ. 26 (1949) 254.

9) Verneuil : La Nature 32 (1904) 177.

10) C. H. Moore : Mining Transaction 184 (1949) 1029.

11) W. H. Bauer: 'J. Amer.Ceram.Soc. 33 (1950) 140

12）滰貞男, 國富稔：山梨大学工学部報告 3 (1947) 47.

13）滰貞男, 國富稔：山梨地方講演会 10 月 3 日

14) B.W. Anderson : The Gemmologist. 16 (1948) 161.

15) C. H. Moore : Mining Transaction 184 (1949) 1029.

あとがき 本多光太郎博士は生前，炭素を凝結して高溫高圧下においてダイヤモンドを合成して貧乏な日本を世 界一富有な國にしたいといって抢られた。本多博士はすでに天上の人となる。その素志をつぐ高分子科学者は誰 か? 國富博士の論說から何かのヒントをつかんでくだされば幸である。(まらい)

\section{高分子化学目次 \\ 第 11 卷・第 105 号 ・ 1954}

\section{[物 理〕}

[1] 結晶性高分子物に関与る研究 . 植松市太郎・滰 沢 章……1 1 第 4 報結晶化の機構について

[2] 逐次分別法の吟味

[化 学]

[3４］アセチレンによる加圧ビニル化反礁生成物に䦥する研究…有 富 勇 美・秦 弘……14

第 4 報 アルキルビニルエーテルとアクリロニトリルとの共重合………........................................ 14

第 5 報 イソブチルビニルエーテルとビニリデンクロライドとの共重合………………...................

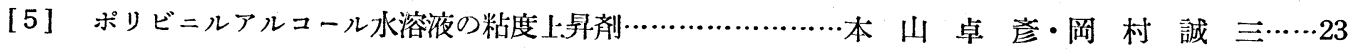

[6] フェノール樹脂に関する研究………………………………井 上良 三・己 波敏 郎……28 第 7 報 アルカリ性におけるメチロール化及びメチレン化の速度について…………………...........28

[7] 石炭酸樹脂の研究……………………………………間 中 和 夫・近 藤 忠 焳……34 第 4 報 酸性触媒におけるフォルムアルデヒドの減少速度と速度恒数比との関係について……….......34 